\title{
An introduction to stable water isotopes in climate models: benefits of forward proxy modelling for paleoclimatology
}

\author{
C. Sturm ${ }^{1,4}$, Q. Zhang ${ }^{1,3}$, and D. Noone ${ }^{2}$ \\ ${ }^{1}$ Bert Bolin Centre for Climate Research, Stockholm University, Stockholm, Sweden \\ ${ }^{2}$ ATOC \& CIRES, University of Colorado, Colorado, USA \\ ${ }^{3}$ Department of Meteorology, Stockholm University, Stockholm, Sweden \\ ${ }^{4}$ Department of Geological Sciences, Stockholm University, Stockholm, Sweden
}

Received: 10 June 2009 - Published in Clim. Past Discuss.: 30 June 2009

Revised: 25 January 2010 - Accepted: 1 February 2010 - Published: 26 February 2010

\begin{abstract}
Stable water isotopes have been measured in a wide range of climate archives, with the purpose of reconstructing regional climate variations. Yet the common assumption that the isotopic signal is a direct indicator of temperature proves to be misleading under certain circumstances, since its relationship with temperature also depends on e.g. atmospheric circulation and precipitation seasonality. Here we introduce the principles, benefits and caveats of using climate models with embedded water isotopes as a support for the interpretation of isotopic climate archives. A short overview of the limitations of empirical calibrations of isotopic proxy records is presented. In some cases, the underlying hypotheses are not fulfilled and the calibration contradicts the physical interpretation of isotopic fractionation. The simulation of climate and its associated isotopic signal, despite difficulties related to downscaling and intrinsic atmospheric variability, can provide a "transfer function" between the isotopic signal and the considered climate variable. The relationship between modelled temperature and isotopic signal is analysed under present-day, pre-industrial and midHolocene conditions. The linear regression relationship is statistically more significant for precipitation-weighted annual temperature than mean annual temperature, yet the regression slope varies greatly between the time-slice experiments. Temperature reconstructions that do not account for the slope variations will in this case underestimate the lowfrequency variability and overestimate high-frequency variability from the isotopic proxy record. The spatial variability of the simulated $\delta^{18} \mathrm{O}$-temperature slope further indicates that the isotopic signal is primarily controlled by synoptic atmospheric circulation rather than local temperature.
\end{abstract}

Correspondence to: C. Sturm (christophe.sturm@geo.su.se)

\section{Introduction}

Climate change has become a major concern in recent years for scientists, policy makers and the general public alike (Solomon et al., 2007). This awareness brings into light two particular aspects of climate research. First, climate is recognised as variable in time. Climate has changed in the past, in response to external (e.g. orbital, volcanic) forcing, and is likely to change in the future due to human activities. Second, climate change is not defined by temperature change alone. The attention is also focused on regional climate change patterns that include precipitation and atmospheric circulation variability. Hence there is a need to understand the mechanisms driving the climate variability. These considerations add a new perspective to paleoclimate research. Reconstructing past climate variability and identifying its drivers improves our understanding of the complex Earth system dynamics, which form the basis for reliable (hence operational) climate predictions.

Over the last decades, a major breakthrough in climate research has been the use of climate models. Global circulation models (GCMs) reproduce the dynamics of the atmosphere coupled to the ocean and land surfaces. One major challenge with GCM studies lies in their validation. If a major climate process is identified in the model world, it needs to be demonstrated that it occurs in the real world as well, i.e. that it is not an artifact caused by the necessarily imperfect model parameterisations. The validation is particularly difficult for past climate simulations, since there are no direct observations of climate variables (e.g. temperature, precipitation amounts, atmospheric pressure) prior to 1750 . We can only rely on indirect indicators (referred to as climate proxies), which require proper interpretation to reconstruct past climate change.

Published by Copernicus Publications on behalf of the European Geosciences Union. 
Stable water isotopologues $\left(\mathrm{H}_{2}^{18} \mathrm{O}\right.$ and $\left.\mathrm{HDO}\right)$, commonly referred to as stable water isotopes (SWI), are widely used as climate proxies. They can be seen as a "common currency" among many different types of climate archives. SWI have been measured directly in ice-cores and in the ${ }^{18} \mathrm{O}$ signature of lake and marine sediments, speleothems, tree-ring and peat-bog cellulose, etc. The inclusion of SWI fractionation parameterisations in climate models (Jouzel et al., 1987b; Hoffmann et al., 1998), an example of "forward proxy modelling", makes it possible to compare directly model output with the measured isotopic data from climate archives, without requirement of a prior reconstruction of climate variables (known as "inverse proxy modelling").

The present article aims to present the principles, benefits and caveats of applying GCM with SWI diagnostics in paleoclimatology. The first section introduces a historical overview of the "classical" interpretation of isotopic climate archives, highlighting some inherent limitations of the inverse proxy modelling approach. The second section presents the main principles for the implementation of SWI in climate models. Rather than entering into technical details, it aims to present which scientific questions can and cannot be addressed with SWI-enabled GCMs. The last section illustrates the issues raised in the previous sections. By comparing simulations by the CAM3iso climate model of present-day (1975), pre-industrial (1750) and mid-Holocene (6 ka BP) time-slices, we focus on the importance of atmospheric circulation and seasonality changes to explain the non-linearity between temperature and SWI composition of precipitation.

\section{Empirical climate reconstruction from isotopic archives}

\subsection{Dansgaard temperature effect}

SWI have been measured in water samples (rain, ocean surface, polar snow, lakes or rivers) since the early 1950s. The isotopic composition is given as a deviation from the ocean reservoir with the delta notation, in permille: $\delta^{18} \mathrm{O}=\left(R_{\text {sample }} / R_{\mathrm{SMOW}}-1\right) \cdot 1000$, where $R=\left[\mathrm{H}_{2}^{18} \mathrm{O}\right] /\left[\mathrm{H}_{2}^{16} \mathrm{O}\right]$ is the concentration ratio between the heavier isotopologue and the common water molecule, SMOW stands for Standard Mean Ocean Water. The same notation is applied for water molecules including deuterium (HDO) to define $\delta D$. From 1961 onwards, the International Atomic Energy Agency (IAEA) and the World Meteorological Organisation (WMO) initiated the Global Network for Isotopes in Precipitation (GNIP) (Schotterer et al., 1996). A first synthesis and interpretation of the global isotopic measurements was presented by Dansgaard (1964).

In this founding article, Dansgaard states that "one cannot use the composition of the individual rain as a direct measure of the condensation temperature". Yet, "a simple linear correlation between annual mean values of the surface temperature and the ${ }^{18} \mathrm{O}$ content in high-latitude, non-continental precipitation" can be obtained over Greenland, provided that "considerable accumulation occurs both in summer and winter", "the trajectories of precipitating air masses are roughly the same", "no considerable ablation takes places" and "topography of the considered area is simple". Under these conditions, the fractionation of heavy isotopes in precipitation corresponds to a Rayleigh distillation process (i.e. progressive process with immediate removal of the condensate from the vapour after formation). Therefore, the $\delta^{18} \mathrm{O}$ will show a significant correlation with the condensation temperature. Under the assumption that the vertical temperature profile in the atmosphere is roughly constant over the considered period, the mean annual condensation and surface temperatures will also be correlated, giving $\delta^{18} \mathrm{O}=0.67 \cdot T_{\text {surf }}-13.6$ (Dansgaard, 1964).

The sum of conditions to be met when using the isotopic signal as a paleo-thermometer highlight the precautions needed before extending this method to isotopic archives other than Greenland ice-cores.

\subsection{Application to isotopic archives}

Following Dansgaard's initial work, the isotopic paleothermometer was used to reconstruct temperature changes over several glacial cycles from polar ice-cores. The recovery of long ice-cores from Antarctica (e.g. Vostok; Jouzel et al., 1987a, and Dome C; EPICA, 2004) as well as from Greenland (e.g. GRIP; Johnsen et al., 1995) revealed variations of $\delta^{18} \mathrm{O}$ over several glacial cycles. Concomitant observations of temperature and $\delta^{18} \mathrm{O}$ were required in order to determine the $\delta^{18} \mathrm{O}$-temperature relationship. Since no longterm observations of both $\delta^{18} \mathrm{O}$ and temperature were available at these sites (for obvious logistical reasons), snow was sampled along traverses to determine the spatial slope of the $\delta^{18} \mathrm{O}$-temperature regression, which was then used as an analogue for the temporal slope on which the paleo-thermometer relies. The validity of the method is discussed in Jouzel et al. (1997). Borehole thermometry represents an alternative method to reconstruct past temperature variations from the drilling site, independent of the $\delta^{18} \mathrm{O}$ signal. Knowing the (slow) diffusion of heat through the ice-sheet, the temperature profile along the drilling hole can be deconvoluted into variations of surface temperature. The estimates of temperature changes over Greenland between present-day and the Last Glacial Maximum (LGM) showed significant discrepancies between the methods. The $\delta^{18} \mathrm{O}-\mathrm{T}$ regression method implies only half of the temperature drop derived from borehole thermometry. These results were used by Johnsen et al. (2001) to determine a quadratic fit of $\delta^{18} \mathrm{O}$ versus temperature, by combining borehole and $\delta^{18} \mathrm{O}$ observations to obtain the best estimate of temperature changes over Greenland. A modelling study by Werner et al. (2000) provided a physical explanation for the discrepancy between both methods, 
related to a change in snowfall seasonality. According to a high-resolution simulation by ECHAM4 with embedded isotopes, most of the precipitation under LGM conditions occurred between May and September, while the precipitation peak today occurs between September and November. Hence the present-day regression of mean annual $\delta^{18} \mathrm{O}$ versus temperature was biased towards late autumn values, while the LGM $\delta^{18} \mathrm{O}$ mainly records summer temperature. The borehole method on the other hand is not sensitive to the precipitation seasonality and therefore more truly represents mean annual temperature estimates.

The interpretation of $\delta^{18} \mathrm{O}$ as a climate proxy was also performed in non-polar environments. Ice-cores have been drilled in the (sub-)Tropics at high altitudes, e.g. in the Andean Cordillera in South America or summits in the Tibetan Himalayas (Thompson, 2000). On-site monitoring campaigns indicate that the isotopic signal under tropical conditions is not significantly correlated with temperature variations (Vimeux et al., 2005). Water isotopes rather record the intensity of precipitation and can therefore be used to reconstruct past variability of the wet season. Furthermore, the interpretation of the isotopic signal is complicated to a larger extent than for polar environments by the impact of neighbouring vegetation, the origin of the moisture and convective processes.

The analysis of $\delta^{18} \mathrm{O}$ in ice-cores has long been a preferred paleoclimate approach, because the precipitation signal is recorded with only little post-deposition alteration. Unfortunately, the geographical extent of ice-caps suitable for isotopic analysis is limited, while the regionalisation of (past and future) climate change has become a major challenge for the climate community. The analysis of the isotopic signal recorded in terrestrial archives can therefore fill the gap from low to high latitudes. These include e.g. lake sediments (with $\delta^{18} \mathrm{O}$ records from ostracode calcite, diatom silica or aquatic cellulose), Sphagnum in peat-bogs, tree-ring cellulose or speleothem calcite. All these archives have a particular record length and resolution, and take up ${ }^{18} \mathrm{O}$ from original precipitation in different ways, each affected by seasonality. Nevertheless, all terrestrial isotopic proxies are related to the hydrological cycle, and ${ }^{18} \mathrm{O}$ can therefore be regarded as a "common currency" to combine available proxy records into a comprehensive picture of climate change. The physical interpretation of the $\delta^{18} \mathrm{O}$ signal in terrestrial archives is challenging, because on top of the processes governing the $\delta^{18} \mathrm{O}$ variability in precipitation, local hydrological (runoff, infiltration, evaporation) and biological processes need to be accounted for.

\subsection{Inherent limitations of temperature- $\delta^{18} \mathrm{O}$ regressions}

As illustrated by the studies above, the reconstruction of temperature based on an isotopic archive is far from trivial. We can summarise the major issues raised in the discussions with the following items.

\section{(Non-)Stationarity of the $\mathbf{T}-\delta^{18} \mathrm{O}$ relationship}

One major limitation with empirical climate reconstructions (or inverse proxy modelling) is the assumption that the isotopic signal is controlled by a single climate variable (e.g. temperature) in a uniform way throughout the entire proxy record. In other words, by applying the regression between $\delta^{18} \mathrm{O}$ and e.g. temperature as obtained over the calibration period, one makes the implicit assumption that the relationship remains valid over the entire proxy record (Masson-Delmotte et al., 2008; Masson-Delmotte et al., 2006). In real cases, this stationarity assumption is rarely fulfilled, since climatic changes will often imply modifications of the atmospheric circulation patterns and changes in seasonality as outlined below.

\section{Impact of changing atmospheric circulation patterns}

The isotopic composition of precipitation (and hence in the climate archive) is a result of fractionation processes along the air mass trajectory. This integrated signal is correlated with local parameters (e.g. local temperature) only as long as the trajectories are roughly similar throughout the study period. When studying large temperature shifts (e.g. over the Holocene), these are likely to imply severe modifications of the regional energy budget, which are likely to affect the regional circulation patterns. Examples of studies investigating the role of atmospheric circulation on the precipitation $\delta^{18} \mathrm{O}$ can be found in Lee et al. (2008); Schneider and Noone (2007); Gregory and Noone (2008); Noone and Simonds (2002).

\section{Impact of changing seasonality}

Many archives used for climate reconstruction are (at most) annually resolved. These annual records are seasonally biased. Ice-cores record a climate signal only when precipitation occurs (Werner et al., 2000), tree-rings grow during summer using summer rain as well as melt water from winter snowfall. If the overall climate is changing, the seasonal distribution of precipitation is likely to be affected, as well as the timing and duration of the growing season.

The present section highlights some of the fundamental advances made in the interpretation of the isotopic signal in climate archives. As mentioned in the cited studies, the reconstructions are based on implicit assumptions that are impossible to verify under past climate conditions. The next section presents how climate models, fitted with stable water isotope diagnostics, can help assessing the temporal and spatial variability of isotopes in precipitation, to support paleoclimate reconstructions. 


\section{Implementation of stable water isotopes in climate models}

\subsection{Fundamentals of climate modelling}

Atmospheric global circulation models (A-GCMs) are computer programmes that reproduce the state and dynamics of the atmosphere in a discrete way. In other words, the atmosphere is approximated by a collection of boxes, with horizontal extent typically in the order of one to five degrees $(100-500 \mathrm{~km})$ and $20-40$ levels in height reaching the lower stratosphere. GCMs are similar to numerical weather forecast models, with the distinction of not being re-initialised with assimilated observations every $6 \mathrm{~h}$.

The GCM code structure is divided into two components: the dynamical core and the physics parameterisations. The GCM dynamical core resolves the primitive equations governing the atmosphere thermodynamics (Bjerknes, 1921). These nonlinear differential equations express the conservation of momentum, energy and mass. The conservation of momentum is expressed by the Navier-Stokes equation, under the assumption of hydrostatic equilibrium (i.e. vertical acceleration is neglected). The conservation of energy is expressed as an energy budget, accounting for radiative processes through the atmosphere and on the Earth surface. The conservation of mass is expressed by the continuity equation, for all considered components of the atmosphere (air, water in vapour, liquid and ice phase). GCMs use different discretisations (e.g. longitude-latitude grids or spherical harmonics, pressure or sigma vertical levels) and optimised algorithms to resolve the primitive equations. The internal time-step of a GCM depends on the grid resolution and algorithm chosen, and is typically in the order of $30 \mathrm{~min}$.

Many processes occurring in the atmosphere cannot be resolved explicitly in the dynamical core, because they happen at much smaller scales. Convective cloud systems for instance develop over an area of a few kilometers, which is two orders of magnitude less than the grid resolution. Convection needs thus to be parameterised, in order to represent the mean precipitation and energy release over the entire gridcell. The changes in prognostic hydrological variables (e.g. atmospheric liquid and vapour content, temperature) related to convection are fed back to the dynamical core, so that the next iteration is computed with updated variables. It is beyond the scope of the present article to describe details of GCM parameterisations. In the next sub-section, we will focus on parameterisations relevant for the inclusion of SWI tracers.

\subsection{Implementation of stable water isotope tracers in GCMs}

The principles for implementing SWI tracers in GCMs are quite simple. The hydrological cycle needs to be duplicated, i.e. every variable in the source code related to water needs to be accompanied by its isotopic counterpart (for $\mathrm{H}_{2}^{18} \mathrm{O}$, HDO, and more recently $\mathrm{H}_{2}^{17} \mathrm{O}$ ). Hence, the dynamical core can advect and mix isotopic tracers from different air masses. In the physical parameterisations, every time a phase change of water takes place (for each internal time-step, i.e. roughly $30 \mathrm{~min}$ ), the equilibrium and kinetic fractionations need to be computed for all water phases (liquid water, vapour and ice), which allows a modification of the isotopic composition of different reservoirs across the globe. Knowing that a GCM source code consists of hundreds of subroutines comprising tens of thousands of code lines, of which at least half are related to the hydrological cycle, the reader will realise what a daunting task it represents to implement the isotopic tracers in the code, even though the underlying physics are relatively simple. It is beyond the scope of the present article to describe the technical aspects of the implementation. For further reading, a good description is given in Noone and Sturm (2009). Hereafter, we will summarise the major steps.

The implementation of isotopic tracers in the dynamical core focuses on the atmospheric prognostic variables (i.e. those needed to compute the state of the atmosphere in the next step). Depending on the GCM structure, the prognostic variables are water vapour, liquid water and/or ice. The inclusion of fractionation processes is treated in the physical parameterisations. Condensation into droplets or ice crystals is treated as an equilibrium fractionation under temperate conditions. The temperature-dependence of the fractionation coefficient was determined from lab experiments (Majoube, 1971). At low temperature, a kinetic correction accounting for the slower diffusivity of heavier isotopes is applied (Jouzel and Merlivat, 1984). These fractionation processes are implemented in the cloud microphysics, typically divided into large-scale (or stratiform) and convective precipitation. Once precipitation is formed in the cloud, up to $80 \%$ re-evaporates in the undersaturated sub-cloud air. This implies a partial isotopic re-equilibration of the rain droplets with surrounding vapour. Small, slowly falling droplets from large-scale precipitation re-equilibrate to $95 \%$, while convective droplets re-equilibrate to $45 \%$ (Hoffmann et al., 1998). This re-equilibration emphasises the importance of isotopic exchanges between the land-surface and precipitation. Precipitation from small droplets will show an imprint of the local air moisture rather than the original cloud signature, which is important to bear in mind for subsequent proxy analysis. This however does not apply to snow, which makes polar archives easier to interpret as climate proxies.

Water fluxes over land play a major role in the isotopic hydrological cycle. The (isotopic) soil moisture keeps a memory of precipitation events (e.g. snow deposited in winter can melt and re-evaporate during summer), and is therefore a prognostic variable. Furthermore, plants evaporate through their leaves almost the entire amount of water taken up by their roots: under steady-state conditions, transpiration is therefore non-fractionating (Bariac et al., 1994). Most 
GCMs in Table 1 represent the soil moisture as a single reservoir (called "bucket" schemes), which does not allow the distinction between evaporation and transpiration. In this case, all evapotranspiration is considered non-frationating. Recent efforts were made to implement isotopic tracers in multi-level soil moisture schemes, which allow the distinction. Such schemes are more appropriate to perform a comparison between terrestrial isotopic archives (e.g. tree-rings, speleothems) and model output. Finally, evaporation from the ocean surface is treated as equilibrium fractionation, with correction for the wind-dependent kinetic effects (Merlivat and Jouzel, 1979).

Following pioneering work in the 1980s (Joussaume et al., 1984; Jouzel et al., 1987b), water isotopes have been implemented in a growing number of GCMs. It is worth noting that most GCMs use very similar formulations for the isotopic fractionations, while the underlying physical parameterisations (e.g. for convection of land-surface water fluxes) are far more diverse. A workshop $\left(\mathrm{SWING}^{1}{ }^{1}-2\right.$ nd Stable Water Isotope iNtercomparison Group) was recently hosted by the Isotopic Hydrology Section at the International Atomic Energy Agency (IAEA, Vienna) to perform an intercomparison of isotope-enabled GCMs and their evaluation against observations of isotopes in precipitation from the Global Network for Isotopes in Precipitation (GNIP, Schotterer et al., 1996). All models participating in SWING2 are listed in Table 1 . The simulations cover the last 50 years (or periods within), with 3 models (ECHAM4, GSM, LMDZ) being nudged to reanalyses (ERA40 or NCEP) ${ }^{2}$. In these cases, the atmospheric circulation is forced to reproduce the observed weather while the (isotopic) water cycle is left unforced, which facilitates the direct comparison between observation and model output. In connection with the 3rd Paleoclimate Modelling Intercomparison Project (PMIP3), it is planned to organise a SWING3 experiment, where participating models will be compared under different climate conditions (e.g. last Millennium, mid-Holocene, Last Glacial Maximum).

In addition to GCMs, SWI were recently implemented in regional climate models (RCMs). The principles are identical, but simulating the climate over a smaller area enables finer resolution (typically one order of magnitude, i.e. horizontal resolutions of $10-50 \mathrm{~km})$. An isotope-enabled regional model needs to be nested in an isotopic GCM, to provide suitable lateral boundary conditions at a 6-h frequency. The jump in resolution imposes a shorter internal time-step, and therefore higher CPU demands. A reasonable simulation period is limited currently to a few decades. The $10 \mathrm{~km}$ limit in horizontal resolution is not simply determined by the

\footnotetext{
${ }^{1}$ SWING2 simulations are available for download on the project's home-page http://people.su.se/ cstur/SWING2/.

${ }^{2}$ Reanalyses represent the assimilation of meteorologic observations worldwide between 1959 and 2001 (ERA40, produced by the European Centre for Midterm Weather Forecast) or 1948 onwards (NCEP/National Center for Atmospheric Research)
}

Table 1. Stable water isotope enabled GCM, participating in the 2nd Stable Water Isotope iNtercomparison Group (SWING2). W.i.p indicates work in progress. More information on the SWING2 project can be found on http://people.su.se/ cstur/SWING2/.

\begin{tabular}{lll}
\hline Model & Institute & References \\
\hline CAM3 & U. Colorado & Noone et al., w.i.p. \\
CAM2 & UC Berkeley & Lee et al. (2007) \\
ECHAM5 & AWI-Bremerhaven & Werner et al., w.i.p. \\
ECHAM4 & MPI-Hamburg & Hoffmann et al. (1998) \\
LMDZ4 & LMD-Paris & Risi et al., submitted \\
MIROC3.2 & JAMSTEC-Yokosuka & Kurita et al. (2005) \\
GSM & Scripps-San Diego & Yoshimura et al. (2008) \\
GISS-E & GISS-New York & Schmidt et al. (2007) \\
GENESIS & Penn U. & Mathieu et al. (2002) \\
ACCESS & ANSTO-Sydney & Fischer et al., w.i.p. \\
HadCM3 & U. Bristol & Tindall et al. (2009) \\
HadAM3 & BAS-Cambridge & Sime et al. (2008) \\
\hline
\end{tabular}

computing capacities. Beyond this threshold, the hydrostatic assumption is no longer valid, nor e.g. the classical parameterisation for convection. To overcome this limitation, highresolution RCMs have been developed recently, in which the water isotopes remain to be implemented. At present, two regional models with embedded isotopic modules exist (Sturm et al., 2005; K. Yoshimura, personal communication, 2008).

\subsection{What can and cannot be expected from isotopic paleo-simulations?}

The preceding two subsections introduced the principles underlying the simulation of SWI within climate models. The present subsection aims to illustrate the benefits of such isotopic GCMs for paleoclimate studies. In particular, we focus on how simulations can complement the conventional interpretation of isotopic climate archives.

A major limitation of climate models is that all phenomena that occur in the real world cannot be adequately represented in the models. In the present article, we do not cover the inherent misfits in climate models. Despite ongoing improvement, the model parameterisations are still far from perfect, which has obvious consequences for the simulated $\delta^{18} \mathrm{O}$ signal. Hence, every study involving climate simulations requires a thorough validation against observations for the study region. The validation of present-day simulations is often restricted by the scarcity of, and inherent measuring errors in observations. It becomes an even more problematic task for simulations of past climates. Besides the technical imperfections, mismatch between observed and simulated variables are related to (1) downscaling issues and (2) intrinsic variability of atmospheric processes.

As described earlier, a climate model reproduces the state of the Earth system on a discrete grid. This implies that direct comparisons with climate variables observed at a given site is 
cannot be made straightforwardly, because the model output typically represents an average over a grid box rather than a value at a local site. The downscaling problem can be addressed with higher resolution climate models (e.g. RCMs). Yet, even when the horizontal resolution is $10 \mathrm{~km}$ instead of $100 \mathrm{~km}$, the fundamental challenge of relating an area average to a point measurement remains. Statistical downscaling methods have been developed to match large-scale conditions with e.g. temperature and precipitation for a given location, taking into account local effects (e.g. leeward or windward setting, small-scale impact of vegetation). Such statistical downscaling methods have not yet been extended to reproduce the isotopic content of precipitation.

The intrinsic variability of climate constitutes an additional difficulty for the comparison between simulations and observations. Given a particular external forcing (e.g. orbital parameters for the insolation), the Earth system can adopt different, equally valid states. Yet the actual (observed) climate represents only one realisation of the many possible climate states. It is therefore not guaranteed that the climate model will reproduce the exact same solution as the one that actually occurred. This challenge has been tackled in different ways by the climate modelling community, which also holds for water isotope simulations. For present-day conditions, it is possible to constrain (or nudge) the atmospheric circulation in the model by reanalyses (i.e. assimilated meteorological observations e.g. ERA40 Uppala et al., 2005). Hence, the nudging technique ensures that a low-pressure system is reproduced roughly at the right place roughly at the right time, while the (isotopic) water cycle is left unconstrained. This enables a direct comparison between simulated and observed isotopic signals. As an example, three models in the SWING2 project (cf. Table 1) delivered nudged simulations over the 1958-2001 period.

Baring the above mentioned limitations in mind, simulations of the $\delta^{18} \mathrm{O}$ signal can be used as a complement to conventional isotopic proxy analyses. The advantages of having embedded water isotope tracers (i.e. forward proxy modelling) is that the model output can be compared directly with the measured proxy (e.g. $\delta^{18} \mathrm{O}$ in ice-cores). Hence, there is no need to derive a change in temperature and/or precipitation (with its associated inversion errors) from the proxy record before comparing it with the output of (nonisotopic) climate models. The isotope-enabled simulation can be seen as a platform, where all simulated variables are physically consistent with each other, and can be known at any location for any time. So even if, due to its intrinsic variability, simulated $\delta^{18} \mathrm{O}$ differs from observations, it is reasonable to assume that the relationship between e.g. temperature and $\delta^{18} \mathrm{O}$ in the model world will be equivalent to that of the real world. Hence, "transfer functions" between $\delta^{18} \mathrm{O}$ and temperature can be derived from the simulation, to be later applied to records of past $\delta^{18} \mathrm{O}$ variations in order to reconstruct actual temperature variations. Based on the internal coherence of the simulated climate, the "trans- fer function" approach can be extended to multi-proxy analysis. The multi-proxy records can both consist of similar climate archives at different locations (e.g. networks of treering cellulose $\delta^{18} \mathrm{O}$ records) and/or different climate proxies at the same site. This will lead to the assimilation of proxy records by forward proxy modelling. By incorporating several proxy records from different sites and origin, it is assumed that noise related to local processes will cancel out, to produce the best estimate of changes in the study area. The a-priori knowledge of spatial patterns and seasonal variations, derived from climate simulations, is optimally combined with available proxy records to reconstruct a physically consistent picture of regional climate change. Furthermore, ensemble simulations deliver sufficient material for a thorough statistical analysis, which can add confidence intervals to the climate reconstructions.

\section{Illustration: impact of radiation forcing on the simulated isotopic composition of precipitation}

\subsection{Experimental settings for the three simulations}

The NCAR Community Atmosphere Model (CAM3.0) with embedded stable water isotopes was used to perform three sensitivity experiments. The model was run on a $128 \times 64$ grid, i.e. with a horizontal resolution of $2.8^{\circ} \times 2.8^{\circ}$ (roughly $300 \mathrm{~km}$ ) and 19 vertical levels. The simulations represent present-day, pre-industrial and midHolocene climate conditions, respectively. The present-day simulation was performed according to the AMIP1 protocol (Gates et al., 1999), using the HadISST/Reynolds dataset (Hack et al., 2002) as boundary condition for sea-surface temperature and sea-ice cover. Pre-industrial and midHolocene simulations follow the PMIP2 protocol (Braconnot et al., 2007; Otto-Bliesner et al., 2006), with sea-surface temperature and sea-ice cover from previous simulations with the coupled ocean-atmosphere CCSM3 model (which used CAM3 as atmospheric component). The ice sheet topography and coastlines in all three simulations were set identical to present day.

The greenhouse gases and Earth's orbital parameters for the three simulations are listed in Table 2. In the current study, we consider the pre-industrial simulation to be the reference (control run). The present-day simulation has identical orbital forcing to the reference, but the atmospheric radiative budget is altered by higher concentrations of greenhouse gases $\left(\mathrm{CO}_{2}, \mathrm{CH}_{4}\right.$ and $\left.\mathrm{NO}_{2}\right)$ and aerosols. The main difference in insolation forcing for mid-Holocene, compared to pre-industrial, is related to the orbital parameters, which is represented by the eccentricity, obliquity and precession (Berger, 1978). The orbital parameters express the relative location of the Earth with respect to the sun, which affects the total amount and distribution of solar radiation across seasons. The Northern Hemisphere receives more 
solar radiation during (boreal) summer under mid-Holocene conditions, as illustrated in Fig. 1. The PMIP2 protocol also prescribes a reduction in atmospheric $\mathrm{CH}_{4}$ concentrations for mid-Holocene as compared to the reference simulation.

The time-slice experiments for present-day, pre-industrial and mid-Holocene conditions were performed over a 40year period, with climatological (identical year-to-year, but with seasonal variations) boundary conditions for sea-surface temperature and sea-ice cover. The first 10 years of the simulations were disregarded as spin-up (i.e. time needed by the climate model to reach a quasi-equilibrium from the initial conditions). The remaining 30 years are used to analyse the intrinsic variability of atmospheric processes, and provide sufficient data for statistically significant time regressions. It is beyond the scope of the present article to assess the validity of the climate simulations for different time-slices. We will focus on the induced changes in simulated temperature, precipitation and $\delta^{18} \mathrm{O}$ by varying radiation and sea-surface boundary conditions, and their implications on the interpretation of $\delta^{18} \mathrm{O}$ as a climate proxy.

\subsection{Spatial patterns and seasonal variation in the reference run}

The current modelling study does not consider the validation of the simulated climate and $\delta^{18} \mathrm{O}$ against observations or proxy records for any time-slice experiments, since thorough validation of the CAM3 GCM and its isotopic module were evaluated previously. The analysis below focuses on model simulations alone (judged to be reasonably realistic, based on previous experience), as a tool to evaluate and illustrate the spatio-temporal variability of $\delta^{18} \mathrm{O}$ and related climate variables.

The analysis of the reference run (pre-industrial radiation settings) introduces general features of GCM-simulated climate. The upper row in Fig. 2 shows the annual, winter and summer mean temperatures. As commonly expected, temperature undergoes a strong latitudinal control, with temperatures declining at higher latitudes. Furthermore, continentality imposes an additional control on temperature. At a given latitude, temperature tends to decrease with increasing distance from the coast. This effect is not symmetrical, the temperature gradually decreases following the direction of the dominant winds. Therefore, the westerlies cause a west-east decreasing gradient over Eurasia, reaching lowest temperatures over Eastern Siberia, which is most noticeable in winter.

We aim to focus on the spatial patterns of the simulated $\delta^{18} \mathrm{O}$ signal, as shown in the lower row of Fig. 2. At first order, $\delta^{18} \mathrm{O}$ variations follow the temperature patterns. $\delta^{18} \mathrm{O}$ decreases with higher latitudes, and reaches its minimum in the coldest regions (Greenland, Eastern Siberia). A closer look reveals some differences. The altitude effect characterises the decrease in $\delta^{18} \mathrm{O}$ with height. This is physically related to the Rayleigh distillation that takes place when
Table 2. Greenhouse gases and Earth's orbital parameters in three simulations.

\begin{tabular}{llll}
\hline & Present-day & Pre-industrial & mid-Holocene \\
\hline $\mathrm{CO}_{2}$ (ppmv) & 348 & 280 & 280 \\
$\mathrm{CH}_{4}$ (ppbv) & 1650 & 760 & 650 \\
$\mathrm{NO}_{2}$ (ppbv) & 306 & 270 & 270 \\
Eccentricity & 0.0167724 & 0.016724 & 0.018682 \\
Obliquity ( $\left.{ }^{\circ}\right)$ & 23.446 & 23.446 & 24.105 \\
Angular precession & 102.04 & 102.04 & 0.87 \\
\hline
\end{tabular}

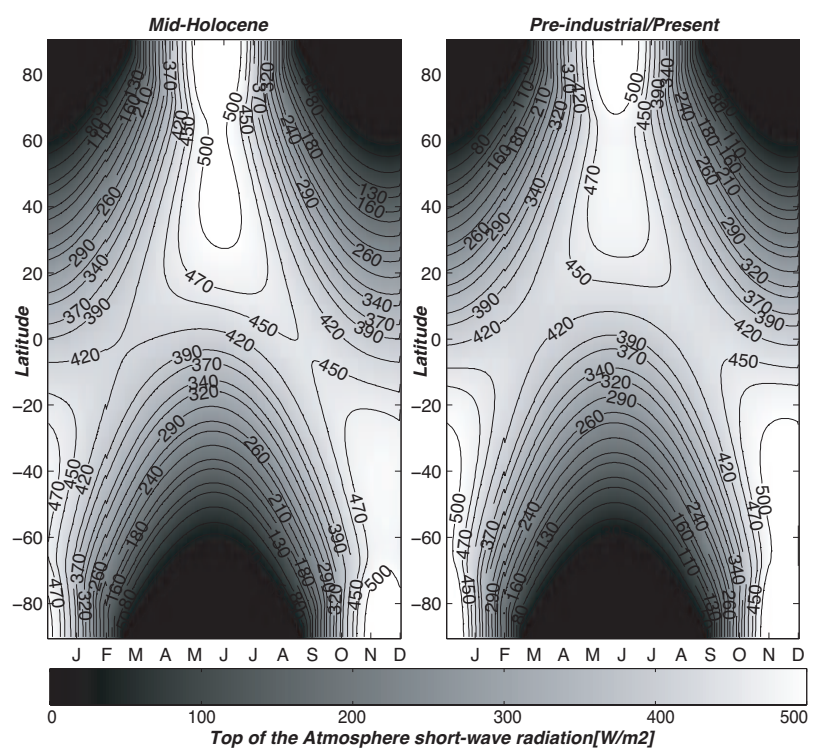

Fig. 1. Comparison of the top-of-the-atmosphere shortwave radiation (i.e. insolation), between the mid-Holocene (left) and presentday (right) situation. The vertical axis represents the latitudes (as the insolation is constant over a given longitude), the horizontal axis represents the month of the year. The seasonal distribution and total intensity of the solar radiation is computed according to the orbital parameters indicated in Table 2 (Berger, 1978).

an air parcel, lifted uphill, condenses to produce isotopically lighter (or depleted) precipitation. This explains the low $\delta^{18} \mathrm{O}$ values over Greenland $(-25$ to $-30 \%$ all year round), more depleted than expected for the temperature change alone. Furthermore, $\delta^{18} \mathrm{O}$ experiences a stronger $c o n$ tinental effect than temperature. At a given latitude, $\delta^{18} \mathrm{O}$ decreases across Eurasia from $-15 \%$ at Norway's Atlantic coast to $-30 \%$ in Eastern Siberia in winter. The continental $\delta^{18} \mathrm{O}$ effect is largely muted in summer, since the nonfractionating evapotranspiration recycles isotopically heavier moisture along the westerly trajectories.

In conclusion, the geographical patterns in temperature and $\delta^{18} \mathrm{O}$ indicate that both are to a large extent controlled by atmospheric circulation, which explains the similar geographical patterns (rather than a strict physical control of local temperature on local $\delta^{18} \mathrm{O}$ in precipitation). Furthermore, 

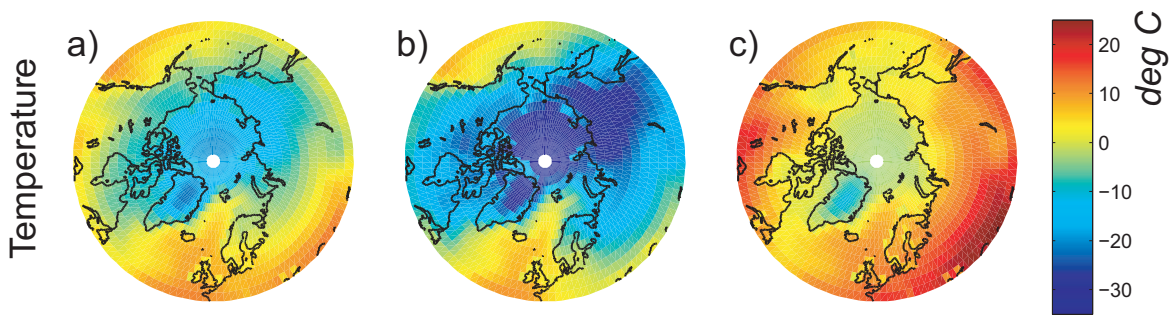

Annual
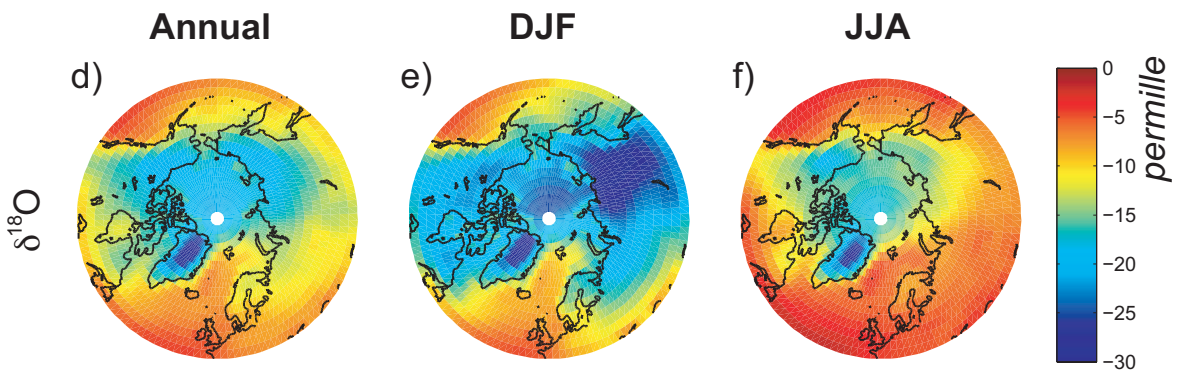

Fig. 2. Stereographic plots of the Northern Hemisphere (at latitudes above 45 degrees) for the pre-industrial simulation, taken as reference run. In the upper (lower) rows, the temperature ( $\delta^{18} \mathrm{O}$ in precipitation) is shown. The left column displays the annual mean, the middle column the winter (DJF) mean and the right column the summer (JJA) mean. The colour bars are common to all subfigures in the row.

the annual means in temperature and $\delta^{18} \mathrm{O}$ result from a combination of seasonal processes, which are not necessarily related to each other. Therefore, deducing the processes of climate change from annually resolved archives is not straightforward.

\subsection{Temperature and precipitation $\delta^{18} \mathrm{O}$ response under various climate conditions}

Temperature at $2 \mathrm{~m}$ and $\delta^{18} \mathrm{O}$ show distinctive responses to changes in boundary conditions (insolation, greenhouse gas and aerosol concentrations, sea-surface temperature, sea-ice extent). We consider here the difference from the reference (pre-industrial) for both temperature and $\delta^{18} \mathrm{O}$. In the case of the mid-Holocene simulated temperature (Fig. 3, upper row), the area-weighted means for the Northern Hemisphere (north of $45^{\circ}$ ) differ little from the reference: $0.24^{\circ} \mathrm{C}$ for the annual mean, $0.09^{\circ} \mathrm{C}$ for the winter mean, and $1.00^{\circ} \mathrm{C}$ for the summer mean. Differences are small for the simulated $\delta^{18} \mathrm{O}$ as well (Fig. 3, lower row): $0.17 /-0.06 / 0.46 \%$ o for annual/winter/summer mean. Observing the strongest deviations during summer is consistent with the insolation changes (Fig. 1). The results presented on Fig. 3 are consistent with following studies with CAM3/CCSM3 (Otto-Bliesner et al., 2006), which confirm that CAM 3 results lie close to the mean of participating GCMs (Braconnot et al., 2007). The spatial mean difference is more pronounced for the present-day simulation (Fig. 4, upper row): $2.41{ }^{\circ} \mathrm{C}$ for the annual mean, $1.58^{\circ} \mathrm{C}$ for the winter mean, and $3.26^{\circ} \mathrm{C}$ for the summer mean. The temperature changes between pre-industrial and present-day conditions are in line with previous estimates: $2.5^{\circ} \mathrm{C}$ terrestrial temperature increase north of $65^{\circ}$ between
1850 and 2005 (IPCC-AR4 report, Chap. 3, Fig. 3.7, Trenberth et al., 2007) and $2^{\circ} \mathrm{C}$ increase in terrestrial temperature north of $60^{\circ}$ between 1900 and 2003 (ACIA report, Chap. 2, Fig. 2.6, McBean et al., 2004). The spatially averaged $\delta^{18} \mathrm{O}$ shows more enriched values for the present-day than the reference simulation for all seasons: $0.59 / 0.12 / 0.87 \%$ for annual/winter/summer mean.

Despite modest changes in spatially averaged temperature and $\delta^{18} \mathrm{O}$, spatial patterns show larger regional differences, reaching up to $\pm 10^{\circ} \mathrm{C}$ and $\pm 5 \%$ o for the present-day simulation. The patterns of temperature and $\delta^{18} \mathrm{O}$ differences are co-located at first order. Regions where temperature shows a positive deviation generally coincide with regions with positive $\delta^{18} \mathrm{O}$ deviations. Yet a closer look reveals that nonlinearity occurs. The temperature deviation on Greenland's east coast (Fig. 4a) is around $+2{ }^{\circ} \mathrm{C}$ (i.e. close to the domain mean), while the $\delta^{18} \mathrm{O}$ deviation (Fig. $4 \mathrm{~d}$ ) is below $-2 \%$, i.e. a large deviation of opposite sign. This counter-intuitive observation cannot be explained physically other than by a modification of the atmospheric circulation. Many other examples can be found in Fig. 4 and, to a lesser extent, in Fig. 3.

Figure 5 presents the climatology (i.e. mean annual cycle) of precipitation, $\delta^{18} \mathrm{O}$ and temperature at two sites: site A is located at $\left[57.2^{\circ} \mathrm{N} ; 7.09^{\circ} \mathrm{E}\right]$ in southern Norway, site B is located at $\left[57.2^{\circ} \mathrm{N} ; 154.5^{\circ} \mathrm{E}\right]$ on the Kamchatka Peninsula, as indicated in Fig. 5. Temperature climatologies at both sites are similar in the pre-industrial and mid-Holocene simulations, only slightly warmer in summer and autumn, but colder in spring than present-day. These temperature differences are related to orbital parameters, as illustrated in Fig. 1. Temperature differences for the present-day simulation are much larger (from 2 to $10^{\circ} \mathrm{C}$ ), but the maximum deviations 

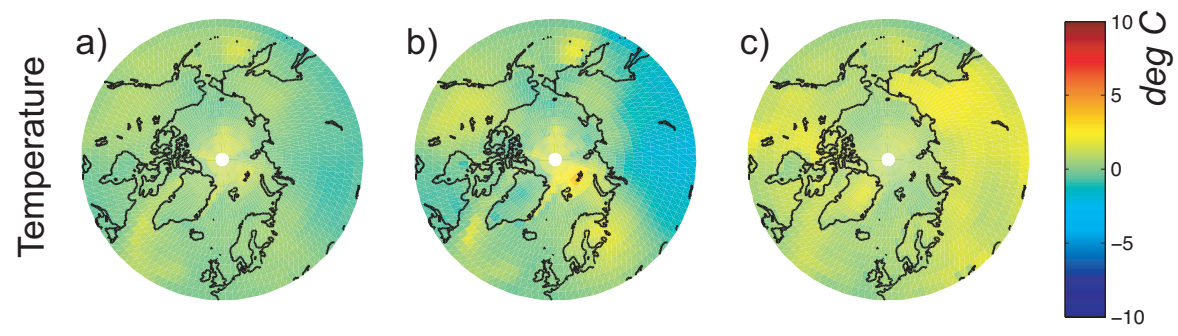

Annual

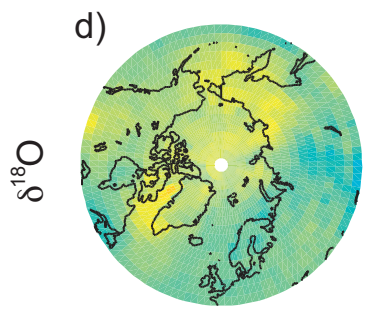

DJF

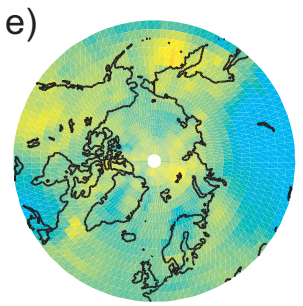

JJA

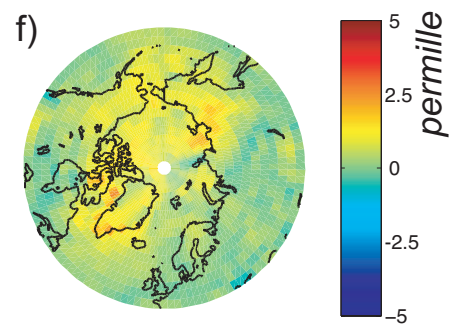

Fig. 3. Using the same projection as in Fig. 2, the difference between the mid-Holocene and the reference (i.e. pre-industrial) simulations for temperature (upper row) and $\delta^{18} \mathrm{O}$ (lower row), for annual (left column), winter (December-February, central column) and summer (June-August, right column) means.

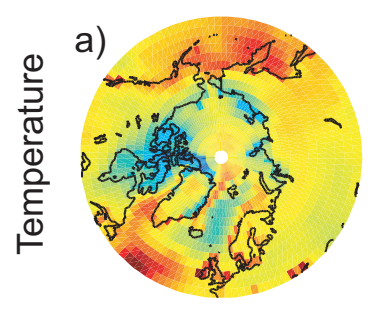

Annual

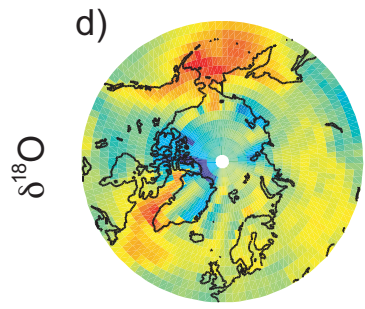

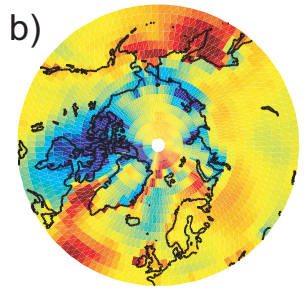

DJF

e)

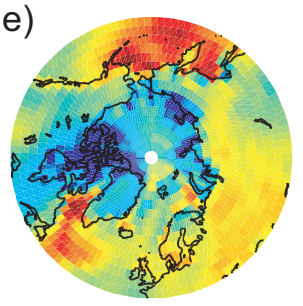

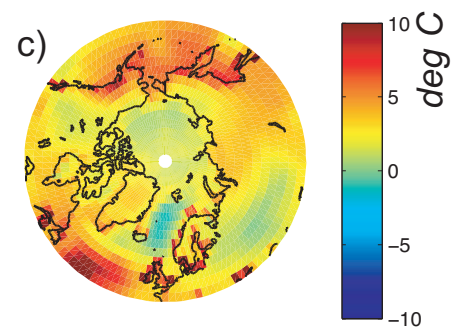

JJA

f)

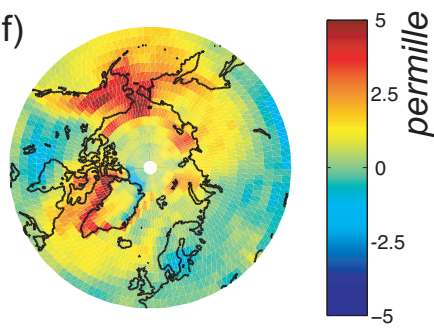

Fig. 4. The sub-figures are identical to Fig. 3 for the differences between present-day and the reference (i.e. pre-industrial) simulation.

occur at different seasons: summer for site A, winter for site $\mathrm{B}^{3}$. The precipitation climatologies show a significant

\footnotetext{
${ }^{3} \mathrm{~A}$ closer look at the lower boundary conditions (sea-surface temperature and sea-ice coverage, from the HadSST and CCSMPMIP2 datasets, not shown) reveals the cause for the large temperature differences at site A between modern and past conditions. Nearby ocean grid cells for mid-Holocene, pre-industrial and modern time slices show a mean annual temperature of $1.0^{\circ} \mathrm{C}, 0.7^{\circ} \mathrm{C}$ and $5.1^{\circ} \mathrm{C}$, respectively. Sea-ice coverage displays $16 \%, 18 \%$ and $8 \%$ respectively. Hence the temperature variations at coastal site A reflect local prescribed ocean conditions, which are much larger than e.g. the mean temperature difference over Scandinavia, as
}

change in the annual distribution of precipitation. For site A, the precipitation maximum is shifted from December to October between present-day and earlier periods, while summer precipitation is doubled and winter precipitation similar. Site $B$ experiences a wetter climate all-year round, the change being strongest (2.4 ratio) during winter. Changes in the precipitation $\delta^{18} \mathrm{O}$ between the pre-industrial and mid-Holocene simulations are more strongly marked than for precipitation or temperature, which indicates that ${ }^{18} \mathrm{O}$ is an integrative proxy recording more than the local climate variations. For

shown in Fig. 4a-c. 



Fig. 5. Climatology (i.e. mean annual cycle) for precipitation, $\delta^{18} \mathrm{O}$ and $2-\mathrm{m}$ temperature (respectively left, middle and right column) at two selected sites: site A $\left(\left[57.2^{\circ} \mathrm{N} ; 7.09^{\circ} \mathrm{E}\right]\right.$, upper row $)$ and site $\mathrm{B}\left(\left[57.2^{\circ} \mathrm{N} ; 154.5^{\circ} \mathrm{E}\right]\right.$, lower row $)$, as indicated in Fig. 7.

site $\mathrm{A}$ in the present-day simulation, $\delta^{18} \mathrm{O}$ is strongly enriched in winter but depleted in summer. This can be empirically interpreted as a "temperature effect" in winter and "amount effect" in summer, although results plotted in Fig. 5 do not allow to differentiate between local and synoptic climate impact on the $\delta^{18} \mathrm{O}$ signature. This highlights a fundamental feature in climate change. As the external forcings vary, the atmospheric circulation and land-surface processes are affected, which can significantly modify both the amount and the timing of precipitation over a given area. This has important consequences for the interpretation of the $\delta^{18} \mathrm{O}$ signal.

\subsection{Local $\delta^{18} \mathrm{O}$-temperature slope: variation in space and time}

The previous section highlights the need to consider the geographical patterns of temperature and $\delta^{18} \mathrm{O}$ changes (and hence the role of atmospheric circulation). We now focus on the $\delta^{18} \mathrm{O}$-temperature relationship, and how it changes under different climate conditions. As originally proposed by Dansgaard (1964), the linear relationship between temperature and $\delta^{18} \mathrm{O}$ in precipitation is generally computed as the regression between the mean annual temperature and the mean precipitation-weighted $\delta^{18} \mathrm{O}$. Under the assumption that precipitation $\delta^{18} \mathrm{O}$ is an indicator for local temperature, only temperature at times when precipitation occurs can be recorded in the $\delta^{18} \mathrm{O}$ signal. Hence, it appears physically more relevant to compute a linear regression between precipitation-weighted temperature and precipitationweighted $\delta^{18} \mathrm{O}$. Climate simulations with embedded isotopes provide an adequate data-set to assess the strength and significance of the temperature- $-\delta^{18} \mathrm{O}$ relationship for both def- initions of temperature average. Analogously to proxy calibration, we computed the temporal $\delta^{18} \mathrm{O}$-temperature slope for every grid cell. A linear (least-square) regression was computed for each grid cell from 30-year long experiments for present-day, pre-industrial and mid-Holocene conditions. The correlation coefficient between temperature and $\delta^{18} \mathrm{O}$ is computed for each grid cell and each experiment.

We investigate the relationship between annual temperature and $\delta^{18} \mathrm{O}$ at two sites in Fig. 6. For site $\mathrm{A}$ and $\mathrm{B}$, whose climatology are shown in Fig. 5, we compute linear regressions between $\delta^{18} \mathrm{O}$ and mean annual or precipitation-weighted temperature. When comparing the $\delta^{18} \mathrm{O}$-temperature regression for site A (Fig. 6, upper two rows), it appears that the precipitation weighting reduces the spread in annual $\delta^{18} \mathrm{O}$-temperature pairs. On the other hand, the weighting has only little influence on the regression slope. The $\delta^{18} \mathrm{O}$-temperature slopes, ranging from 0.3 to $2.1\left[\% /{ }^{\circ} \mathrm{C}\right]$ depend most strongly on the time-slice specific climate conditions. The $\delta^{18} \mathrm{O}-\mathrm{T}$ regression at site $\mathrm{B}$ for unweighted temperature produces negative slopes (denoted as $\alpha$ in the legend), which appear unrealistic with regard to physical fractionation processes. After weighting monthly temperature with precipitation amounts, the spread in individual yearly means is reduced and the weighted regression slopes are physically coherent. The $\delta^{18} \mathrm{O}$-temperature slopes for the three time-slice experiments vary from 0.21 to 0.48 $\left[\% o /{ }^{\circ} \mathrm{C}\right]$.

The regression results for sites $\mathrm{A}$ and $\mathrm{B}$ can be used to assess the validity of an empirical $\delta^{18} \mathrm{O}$-temperature calibration method, tested with model output. It appears physically more relevant and statistically more robust to reconstruct precipitation-weighted temperature rather 

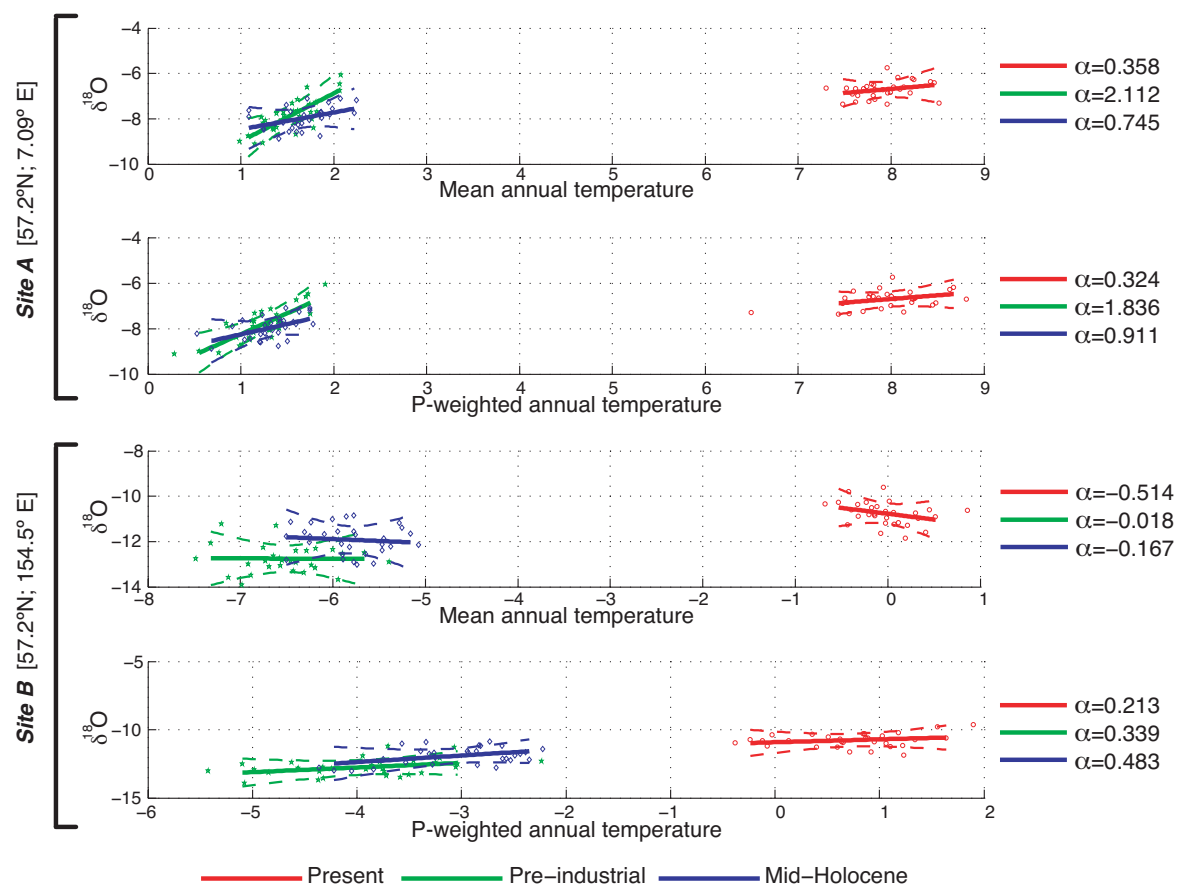

Fig. 6. Linear regression of $\delta^{18} \mathrm{O}$ versus temperature, for site $\mathrm{A}\left(\left[57.2^{\circ} \mathrm{N} ; 7.09^{\circ} \mathrm{E}\right]\right.$, two upper row) and site $\mathrm{B}\left(\left[57.2^{\circ} \mathrm{N} ; 154.5^{\circ} \mathrm{E}\right]\right.$, two lower row), as indicated in Fig. 7. Markers indicate individual annual values, full lines the linear regression and dashed lines the $99.99 \%$ confidence interval for the regression. Similar to Fig. 7, the upper/lower row for each site shows the regression against mean/precipitation-weighted annual temperature.

than mean annual temperature. While weighted and unweighted values are close under present-day conditions for both sites (A: $\Delta T^{\text {present }}=T_{\text {weighted }}^{\text {present }}-T_{\text {unweighted }}^{\text {present }}=-0.11^{\circ} \mathrm{C}$, B: $\Delta T^{\text {present }}=0.90^{\circ} \mathrm{C}$ ), they can differ significantly under pre-industrial (A: $\Delta T^{\text {pre-ind. }}=0.34^{\circ} \mathrm{C}, \mathrm{B}: \Delta T^{\text {pre-ind. }}=$ $2.68^{\circ} \mathrm{C}$ ) and mid-Holocene (A: $\Delta T^{\text {mid-Hol. }}=0.33^{\circ} \mathrm{C}$, B: $\Delta T^{\text {mid-Hol. }}=2.90^{\circ} \mathrm{C}$ ) conditions. Hence, one drawback of local $\delta^{18} \mathrm{O}$-temperature regression methods would be that only mean precipitation-weighted temperature can be robustly reconstructed from annual $\delta^{18} \mathrm{O}$ precipitation records. Yet precipitation-weighted temperature cannot be directly related to mean annual temperature, since the difference varies in both space and time. The second issue to be tested with the time-slice experiments is the time variability of the $\delta^{18} \mathrm{O}$ temperature slope (all temperatures mentioned below are precipitation-weighted yearly values at a given site). In other words, what errors can arise from assuming that a $\delta^{18} \mathrm{O}$ temperature calibration obtained under present-day conditions is valid for pre-industrial and mid-Holocene climate conditions? At site A, taking the present-day regression coefficient $\Delta \delta^{18} \mathrm{O} / \Delta T_{\text {weighted }}=0.32 \% /{ }^{\circ} \mathrm{C}$ with a $\delta^{18} \mathrm{O}$ drop over the times slice by $-1.14 \%$ o (pre-industrial) and $-1.25 \%$ o (mid-Holocene) introduces temperature overestimations of $3.38^{\circ} \mathrm{C}$ (pre-industrial) and $2.95^{\circ} \mathrm{C}$ (mid-Holocene). Qualitatively speaking, in the case of site $\mathrm{A}$, the error induced by taking modern calibration of $\delta^{18} \mathrm{O}$ versus mean precipitation- weighted temperature $\left(3^{\circ} \mathrm{C}\right)$ amounts to about half of the temperature difference between the present-day and preindustrial/mid-Holocene simulations $\left(-6.7^{\circ} \mathrm{C}\right)$.

In conclusion, linear regression of local annual $\delta^{18} \mathrm{O}$ versus temperature reveals severe limitations. Mean annual temperature and mean $\delta^{18} \mathrm{O}$ are loosely correlated in large areas (unhatched areas on Fig. 7, left column), so that the linear regression produces numerical artifacts, i.e. values without physical significance (e.g. negative slopes, as at site B). Using precipitation-weighted temperature means limits the spread and increases the statistical significance of the regression. On the other hand, the relationship between precipitation-weighted and mean annual temperatures varies with both space and time. Finally, the calibration technique is hazardous since the $\delta^{18} \mathrm{O}$-temperature relationship is not robust over time. In the example of site A (Fig. 6, upper row), low-frequency variability (i.e. temperature difference between present-day and pre-industrial/mid-Holocene) would be underestimated by a factor two. By applying the present-day calibration $\left(\alpha=0.358 \%\right.$ o $\left./{ }^{\circ} \mathrm{C}\right)$, a $1.3 \%$ o difference between mid-Holocene and present-day $\delta^{18} \mathrm{O}$ gives a reconstructed $3.63{ }^{\circ} \mathrm{C}$ temperature difference, about half of the actual $6.4^{\circ} \mathrm{C}$. Similarly, neglecting the variation in the $\delta^{18} \mathrm{O}-\mathrm{T}$ regression slope leads in this case to the overestimation of short-term temperature variability. Taking the ratio between the calibration slope (for present-day $\alpha=0.358 \%{ }^{\circ} \mathrm{C}$ ) and the regression slope for pre-industrial $\left(\alpha=2.112 \% /{ }^{\circ} \mathrm{C}\right)$ and 

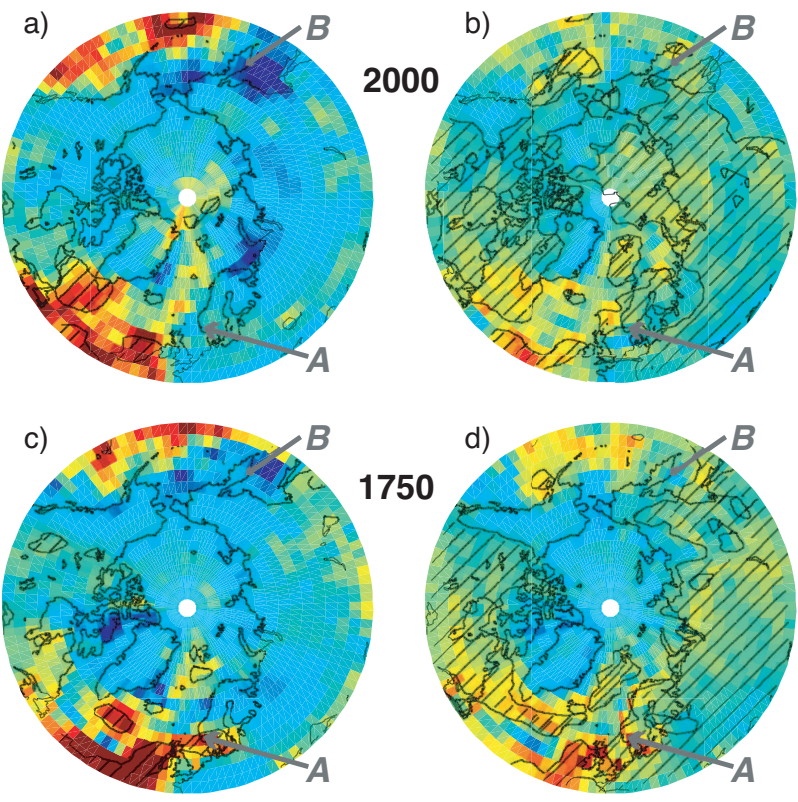

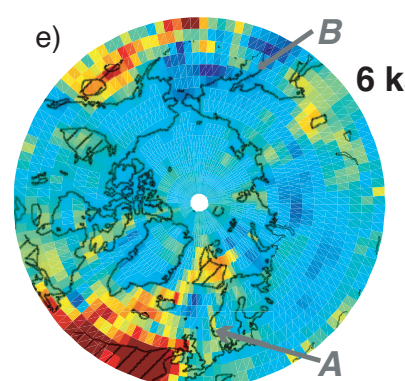

Annual mean $\mathrm{T}$ regression vs $\mathrm{d} 180$

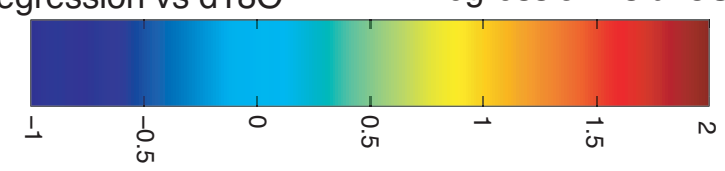

Fig. 7. Linear regressions between the mean annual weighted $\delta^{18} \mathrm{O}$ and temperature at $2 \mathrm{~m}$, computed for each grid cell over the 30 -year experiment period. The shading indicates areas where the regression captures at least $30 \%$ of the variance, i.e. where the correlation coefficient between $\delta^{18} \mathrm{O}$ and temperature exceeds $\sqrt{0.3}=0.5477$. The left column (a, c, e) shows the regression between the weighted $\delta^{18} \mathrm{O}$ and the mean annual temperature. The right column (b, d, f) shows the regression with mean precipitation weighted temperature. The upper/middle/lower rows show regressions for the present-day/pre-industrial/mid-Holocene simulations. The colourbar indicates the regression coefficient in $\% o{ }^{\circ} \mathrm{C}$. The labels $\mathrm{A}$ and $\mathrm{B}$ indicate the location of sites for site analysis in Fig. 5 and Fig. 6.

mid-Holocene $\left(\alpha=0.745 \% /{ }^{\circ} \mathrm{C}\right)$, an inter-annual or interdecadal variation in the $\delta^{18} \mathrm{O}$ proxy by $1 \%$ o leads to a reconstructed temperature variation of $2.8^{\circ} \mathrm{C}$ for both periods, while the actual temperature changes are $0.47^{\circ} \mathrm{C}$ for the pre-industrial and $1.34^{\circ} \mathrm{C}$ for the mid-Holocene case, i.e. an overestimation of the short-term temperature variability by a factor 6 and 2, respectively.

After examining the $\delta^{18} \mathrm{O}$-temperature relationship at two sites, we extend the regression analysis to all grid cells in the domain as shown in Fig. 7: the coloured plots indicate the regression coefficient $\alpha=\frac{\Delta \delta^{18} \mathrm{O}}{\Delta T_{\text {mean }} / \text { weighted }}$, according to the colour scale at the bottom, in $[\% / \mathrm{K}]$. The hatched contours represent regions where the linear regression explains at least $30 \%$ of the variance (i.e. the correlation coefficient is superior to $\sqrt{0.3}=0.5477$ ). When comparing the regression slope of $\delta^{18} \mathrm{O}$ against mean annual (Fig. 7, left column) versus precipitation-weighted temperature (Fig. 7, right column), the most striking feature is the difference in significance (i.e. areas where the regression explains at least $30 \%$ of the common variance between $\delta^{18} \mathrm{O}$ and temperature). With unweighted temperature, only few regions, mainly over the mid-latitude Atlantic Ocean, display a pronounced correlation between mean annual temperature and $\delta^{18} \mathrm{O}$. When using precipitation-weighted mean annual temperature, the common variance with $\delta^{18} \mathrm{O}$ appears to be above $30 \%$ over the Eurasian and North American continents north of $45^{\circ} \mathrm{N}$, except for Alaska, north-east Siberia and Greenland. Over the North Atlantic, the regression expresses more than $30 \%$ of the local variance, with the exception of a south-west/north-east band corresponding to the mean storm track over the Northern Atlantic.

The linear $\delta^{18} \mathrm{O}$-temperature regression produces negative coefficients, which contradicts the physical understanding of water isotope fractionation. Based on the significance maps, we can conclude that none of the negative regression coefficients are statistically significant. Local $\delta^{18} \mathrm{O}$ and temperature are weakly correlated and the statistical value may be considered as a mathematical artifact. On the other hand, significant regression coefficients (with weighted temperature) can vary from 0 up to $2\left[\%{ }^{\circ} \mathrm{C}\right]$, hence the calibration of $\delta^{18} \mathrm{O}$ versus temperature can only be valid for a given area and time. The highest values are found over ocean and coastal regions. This primarily implies that small temperature variations (due to the oceanic climate) are associated with larger isotopic variability (due to the amount effect and/or a change of trajectories). Over both Northern Canada and Siberia, there is a tendency for stronger regression slopes when progressing eastwards. This analysis is consistent with the exponential shape of the Raleigh distillation model, whose derivative will steepen along the trajectory (on average following westerlies). Yet mid-latitude and sub-polar eddies are highly variable, which explains the disorganised distribution of slopes. Furthermore, the location of eddies are controlled by synoptic parameters and can shift in response to different climate conditions. Hence the "west-east gradient in regression slope" is not spatially homogeneous and differs between the time-slice experiments. No significant correlations between $\delta^{18} \mathrm{O}$ and temperature can be found over Greenland in these simulations. There could be two explanations: either 
there is no statistically significant correlation between icecore $\delta^{18} \mathrm{O}$ and local temperature, in which case the $\delta^{18} \mathrm{O}$ signal records the temperature changes over a larger domain, or the model at this resolution proves incapable of reproducing meteorological processes typical for Greenland (e.g. polar precipitation, boundary layer dynamics).

\section{Conclusions}

The isotopic signal in climate archives is a strong climate proxy, yet difficult to interpret because it is influenced by a wide range of climate processes. The $\delta^{18} \mathrm{O}$ signal is commonly interpreted as an indicator of temperature, which requires a calibration under present-day conditions. While $\delta^{18} \mathrm{O}$ at mid- to high latitudes is generally well correlated with temperature, this relationship only holds as long as the dominant atmospheric patterns and the seasonal distribution of precipitation remains stable. Climate models with embedded stable water isotope diagnostics can be used as a tool for assessment of the robustness of the $\delta^{18} \mathrm{O}$-temperature relationship under different climate conditions. For this purpose, the CAM3iso climate model with an embedded water isotope module was run to reproduce present-day, pre-industrial and mid-Holocene climate conditions. The discussion of the temperature and $\delta^{18} \mathrm{O}$ differences unveils the non-linear character of the $\delta^{18} \mathrm{O}$-temperature relationship. With a closer look at two sites (in Southern Norway and on the Kamchatka Peninsula), it becomes apparent that precipitation-weighted mean temperature correlates better with mean annual $\delta^{18} \mathrm{O}$. Yet considering the change in precipitation climatology, weighted temperature does not resolve the change in $\delta^{18} \mathrm{O}$ temperature slope under different climate conditions. When applying the $\delta^{18} \mathrm{O}$-temperature calibration for the south Norwegian site, obtained under present-day conditions, to preindustrial or mid-Holocene $\delta^{18} \mathrm{O}$ changes, the inferred temperature reconstruction would be strongly biased. The reconstructed temperature change would be $-3.6{ }^{\circ} \mathrm{C}$ instead of the actual $-6.4^{\circ} \mathrm{C}$, and furthermore the high-frequency temperature variability (year to decade) would be overestimated by a factor of 2 to 6 . While the change in annual precipitation distribution (and its impact on the $\delta^{18} \mathrm{O}$-temperature slope) can be corrected for with the precipitation-weighted temperature mean, the remaining differences in $\delta^{18} \mathrm{O}$-weighted temperature slopes between different climate periods can only be attributed to a change in atmospheric circulation. The analysis of the $\delta^{18} \mathrm{O}$-temperature relationship is extended to the entire domain of interest. As expected, the correlation of $\delta^{18} \mathrm{O}$ is stronger with precipitation-weighted than mean annual temperature. The $\delta^{18} \mathrm{O}$-temperature slope shows a consistent and logical pattern over the ocean, with the exclusion of storm-tracks.
Our time-slice sensitivity experiments highlight the risks of using local $\delta^{18} \mathrm{O}$-temperature calibration for climate reconstructions and enable the quantification of the biases. Beyond their role as a virtual laboratory, isotope-enabled climate models can shed new light by providing physicallybased "transfer functions" between the isotopic signal and climate, in order to exploit most of the information enclosed in isotopic climate archives. A particular advantage compared to conventional paleoclimatic methods is the ability to make a spatial synthesis of multiple proxies, leading to the assimilation of multiple isotopic proxy data. Further model developments are needed to make the proxy assimilation possible for terrestrial isotopic archives. At present, the forward proxy modelling is restricted to the isotopic composition of precipitation. With the exception of ice-cores, isotopic proxy records do not record directly the $\delta^{18} \mathrm{O}$ of precipitation. Hence, local hydrological and biogeochemical processes need to be implemented in the model, so that the simulated "pseudo-proxy" can be compared directly with the measured isotopic signal in the climate archive. For instance, implementing the isotopic tracers in a hydrological model allows the representation of the isotopic composition of lake-water, from which biological parameterisations can derive the $\delta^{18} \mathrm{O}$ of e.g. aquatic cellulose and ostracode calcite in the model world (hence pseudo-proxy). This approach will account e.g. for the convolution of melt-water pulses, evaporative enrichment of lake waters and the timing of the growing season of ostracodes and acquatic plants under various climate conditions. The pseudo-proxy record can then be directly compared with the observed (isotopic) proxy record. The same procedure can be applied to tree-rings and speleothem $\delta^{18} \mathrm{O}$ records, with the application of site-specific infiltration, tree physiology or cave models. The advantage of such a forward (pseudo-) proxy method is that the sensitivity of the climate reconstruction to changes in atmospheric circulation changes and seasonality can be tested, which is out of reach of empirical regression methods. One further aspect not being addressed in the present study concerns the spatial reconstruction of climate change. Since climate simulations provide a physically coherent and spatially detailed image of climate variations, statistical techniques such as eigenvalue methods can be used to project the observed isotopic signal variability onto regional climate change patterns. For example, $\delta^{18} \mathrm{O}$ records from northern and southern Europe can be combined with the model response patterns, in order to reconstruct past North Atlantic Oscillation activity. Such model-based statistical methods provide an alternative way to distinguish between local and synoptical control on the measured $\delta^{18} \mathrm{O}$ signal, which leads the way to proxy "assimilation" with isotope-enabled climate models. Finally, the sum of data provided by ensemble simulations and modelling sensitivity studies can provide a quantitative assessment of the uncertainties associated with climate reconstructions from combined proxy and modelling evidence. 
Acknowledgements. This work is a result of the workshop on Holocene climate variability over Scandinavia, hosted by the Bert Bolin Centre for Climate Research, Stockholm University, in April 2008. The collaboration between Q. Zhang and D. Noone on CAM3iso modelling was made possible thanks to a visiting grant from the International Meteorological Institute.

Edited by: A. Moberg

\section{References}

Bariac, T., Gonzalez-Dunia, J., Katerji, N., Béthenod, O., Bertolini, J. M., and Mariotti, D.: Spatial variation of the isotopic composition of water $\left({ }^{18} \mathrm{O},{ }^{2} \mathrm{H}\right)$ in organs of aerophytic plants: 2 . Assessment under field conditions, Chem. Geol., 115, 317-333, 1994.

Berger, A. L.: Long-Term Variations of Daily Insolation and Quaternary Climatic Changes, J. Atmos. Sci., 35, 2362-2367, 1978.

Bjerknes, V.: The meteorology of the temperate zone and the general atmospheric circulation, Mon. Weather Rev., 49, 1-3, doi:10.1175/1520-0493(1921)49;1:TMOTTZ ${ }_{i} 2.0 . C O ; 2,1921$.

Braconnot, P., Otto-Bliesner, B., Harrison, S., Joussaume, S., Peterchmitt, J.-Y., Abe-Ouchi, A., Crucifix, M., Driesschaert, E., Fichefet, Th., Hewitt, C. D., Kageyama, M., Kitoh, A., Laîné, A., Loutre, M.-F., Marti, O., Merkel, U., Ramstein, G., Valdes, P., Weber, S. L., Yu, Y., and Zhao, Y.: Results of PMIP2 coupled simulations of the Mid-Holocene and Last Glacial Maximum Part 1: experiments and large-scale features, Clim. Past, 3, 261277, 2007, http://www.clim-past.net/3/261/2007/.

Dansgaard, W.: Stable isotopes in precipitation, Tellus, XVI, 436468, 1964.

EPICA: Eight glacial cycles from an Antarctic ice core, ePICA team: L. Augustin, C. Barbante, P.R.F. Barnes, J.M. Barnola, M. Bigler, E. Castellano, O. Cattani, J. Chappellaz, D. Dahl-Jensen, B. Delmonte, G. Dreyfus, G. Durand, S. Falourd, H. Fischer, J. Flückiger, M.E. Hansson, P. Huybrechts, G. Jugie, S.J. Johnsen, J. Jouzel, P. Kaufmann, J. Kipfstuhl, F. Lambert, VY. Lipenkov, G.C. Littot, A. Longinelli, R. Lorrain, V. Maggi, V. MassonDelmotte, H. Miller, R. Mulvaney, J. Oerlemans, H. Oerter, G. Orombelli, F. Parrenin, DA. Peel, J.R. Petit, D. Raynaud, C. Ritz, U. Ruth, J. Schwander, U. Siegenthaler, R. Souchez, B. Stauffer, J.P. Steffensen, B. Stenni , T.F. Stocker, I.E. Tabacco, R. Udisti, R.S.W. van de Wal, M. van den Broeke, J. Weiss , F. Wilhelms, J.G. Winther, E.W. Wolff, M. Zucchelli, Nature, 429, 623-238, 2004.

Uppala, S. M., KÅllberg, P. W., Simmons, A. J., Andrae, U., Da Costa, B., Fiorino, M., Gibson, J. K., Haseler, J., Hernandez, A., Kelly, G. A., Li, X., Onogi, K., Saarinen, S., Sokka, N., Allan, R. P., Andersson, E., Arpe, K., Balmaseda, M. A., Beljaars, A. C. M., Van De Berg, L., Bidlot, J., Bormann, N., Caires, S., Chevallier, F., Dethof, A., Dragosavac, M., Fisher, M., Fuentes, M., Hagemann, S., Hólm, E., Hoskins, B. J., Isaksen, L., Janssen, P. A. E. M., Jenne, R., Mcnally, A. P., Mahfouf, J. F., Morcrette, J. J., Rayner, N. A., Saunders, R. W., Simon, P., Sterl, A., Trenberth, K. E., Untch, A., Vasiljevic, D., Viterbo, P., and Woollen, J.: The ERA-40 re-analysis, Q. J. Roy. Meteorol. Soc., 131, 2961-3012, 2005.
Gates, W. L., Boyle, J. S., Covey, C., Dease, C. G., Doutriaux, C. M., Drach, R. S., Fiorino, M., Gleckler, P. J., Hnilo, J. J., Marlais, S. M., Phillips, T. J., Potter, G. L., Santer, B. D., Sperber, K. R., Taylor, K. E., and Williams, D. N.: An Overview of the Results of the Atmospheric Model Intercomparison Project (AMIP I), B. Am. Meteorol. Soc., 80, 29-55, doi:10.1175/15200477(1999)080<0029:AOOTRO>2.0.CO;2, 1999.

Gregory, S. and Noone, D.: Variability in the teleconnection between the El Niño Southern Oscillation and West Antarctic climate deduced from West Antarctic ice core isotope records, J. Geophys. Res., 113, D17110, doi:10.1029/2007JD009107, http: //www.agu.org/pubs/crossref/2008/2007JD009107.shtml, 2008.

Hack, J., Hurrell, J., Rosinski, J., and Caron, J.: The NCAR CGD annual Scientific report 2002, Tech. rep., NCAR, 2002.

Hoffmann, G., Werner, M., and Heimann, M.: Water isotope module of the ECHAM atmospheric general circulation model: A study on timescales from days to several years, J. Geophys. Res., 103, 16871-16896, 1998.

Johnsen, S., Dahl-Jensen, D., Dansgaard, W., and Gundestrup, N.: Greenland paleotemperatures derived from GRIP bore hole temperature and ice core isotopic profiles, Tellus, 47B, 624-629, doi:10.1034/j.1600-0889.47. issue5.9.x, http://www.blackwell-synergy.com/doi/abs/10.1034/ j.1600-0889.\%47.issue5.9.x, 1995.

Johnsen, S. J., Dahl-Jensen, D., Gundestrup, N., Steffensen, J. P., Clausen, H. B., Miller, H., Masson-Delmotte, V., ornsdottir, A. E. S., and White, J.: Oxygen isotope and palaeotemperature records from six Greenland ice-core stations: Camp Century, Dye-3, GRIP, GISP2, Renland and NorthGRIP, J. Quaternary Sci., 16, 299-307, 2001.

Joussaume, J., Sadourny, R., and Jouzel, J.: A general circulation model of water isotope cycle in the atmosphere, Nature, 311, 24 29, 1984.

Jouzel, J. and Merlivat, L.: Deuterium and oxygen 18 in precipitation: modeling of the isotopic effects during snow formation, J. Geophys. Res., 89, 11749-11757, 1984.

Jouzel, J., Lorius, C., Petit, J. R., Genthon, C., Barkov, N. I., Kotlyakov, V. M., and Petrov, V. M.: Vostok ice core: a continuous isotope temperature record over the last climatic cycle (160000 years), Nature, 329, 402-408, 1987a.

Jouzel, J., Russel, G. L., Suozzo, R. J., Koster, R. D., White, J. W., and Broecker, W. S.: Simulations of the HDO and $\mathrm{H}_{2}^{18} \mathrm{O}$ atmospheric cycles using the NASA/GISS general circulation model: the seasonal cycle for present-day conditions, J. Geophys. Res., 92, 14739-14760, 1987b.

Jouzel, J., Alley, R. B., Cuffey, K. M., Dansgaard, W., Grootes, P., Hoffmann, G., Jonsen, S. J., Koster, R. D., Peel, D., Shuman, C. A., Stievenard, M., Stuiver, M., and White, J. W.: Validity of the temperature reconstruction from water isotopes in ice cores, J. Geophys. Res., 102, 26471-26487, 1997.

Kurita, N., Sugimoto, A., Fujii, Y., Fukazawa, T., Makarov, V. N., Watanabe, O., Ichiyanagi, K., Numaguti, A., and Yoshida, N.: Isotopic composition and origin of snow over Siberia, J. Geophys. Res., 110, D13102, doi:\{10.1029/2004JD005053\}, http: //dx.doi.org/10.1029/2004JD005053, 2005.

Lee, J., Fung, I., DePaolo, D. J., and Otto-Bliesner, B.: Water isotopes during the Last Glacial Maximum: New general circulation model calculations, J. Geophys. Res., 113, D19109, doi:\{10. 1029/2008JD009859\}, http://www.agu.org/pubs/crossref/2008/ 
2008JD009859.shtml, 2008.

Lee, J.-E., Fung, I., DePaolo, D. J., and Henning, C. C.: Analysis of the global distribution of water isotopes using the NCAR atmospheric general circulation model, J. Geophys. Res., 112, D16306, doi:10.1029/2006JD007657, http://www.agu.org/pubs/ crossref/2007/2006JD007657.shtml, 2007.

Majoube, M.: Fractionnement en oxygène 18 et en deutérium entre l'eau et sa vapeur, J. Chem. Phys., 10, 1423-1436, 1971.

Masson-Delmotte, V., Dreyfus, G., Braconnot, P., Johnsen, S., Jouzel, J., Kageyama, M., Landais, A., Loutre, M.-F., Nouet, J., Parrenin, F., Raynaud, D., Stenni, B., and Tuenter, E.: Past temperature reconstructions from deep ice cores: relevance for future climate change, Clim. Past, 2, 145-165, 2006, http://www.clim-past.net/2/145/2006/.

Masson-Delmotte, V., Hou, S., Ekaykin, A., Jouzel, J., Aristarain, A., Bernardo, R. T., Bromwich, D., Cattani, O., Delmotte, M., Falourd, S., Frezzotti, M., Gallée, H., Genoni, L., Isaksson, E., Landais, A., Helsen, M. M., Hoffmann, G., Lopez, J., Morgan, V., Motoyama, H., Noone, D., Oerter, H., Petit, J. R., Royer, A., Uemura, R., Schmidt, G. A., Schlosser, E., Simões, J. C., Steig, E. J., Stenni, B., Stievenard, M., van den Broeke, M. R., van de Wal, R. S. W., van de Berg, W. J., Vimeux, F., and White, J. W. C.: A Review of Antarctic Surface Snow Isotopic Composition: Observations, Atmospheric Circulation, and Isotopic Modeling*, J. Climate, 21, 3359-3387, doi:10.1175/2007JCLI2139. 1, http://dx.doi.org/10.1175/2007JCLI2139.1, 2008.

Mathieu, R., Pollard, D., Cole, J. E., White, J. W. C., Webb, R. S., and Thompson, S. L.: Simulation of stable water isotope variations by the GENESIS GCM for modern conditions, J. Geophys. Res. (Atmospheres), 107(D4), 4037, doi:10.1029/ 2001JD900255, 2002.

McBean, G., Alekseev, G., Chen, D., Frøland, E., Fyfe, J., Groisman, P., King, R., Melling, H., Vose, R., and Whitfield, P.: Arctic Climate - Past and Present, in: Arctic Climate Impact Assessment: Scientific report, Cambridge University Press, online available at: http://www.acia.uaf.edu/PDFs/ACIA_Science Chapters_Final/ACIA_Ch02_Final.pdf, 2004.

Merlivat, L. and Jouzel, J.: Global climatic interpretation of the deuterium-oxygen 18 relationship for precipitation, J. Geophys. Res., 84, 5029-5033, 1979.

Noone, D. and Simonds, I.: Association between 180 of water and climate paramters in a simulation of atmospheric circulation for 1979-95, J. Climate, 15, 3150-3169, 2002.

Noone, D. and Sturm, C.: Comprehensive dynamical models of global and regional water isotope distributions, in: Isoscapes: Understanding movement, pattern, and process on Earth through isotope mapping, Springer Verlag, 2009.

Otto-Bliesner, B. L., Brady, E. C., Clauzet, G., Tomas, R., Levis, S., and Kothavala, Z.: Last Glacial Maximum and Holocene Climate in CCSM3, J. Climate, 19, 2526-2544, doi:10.1175/JCLI3748.1, http://dx.doi.org/10.1175/JCLI3748.1, 2006.

Schmidt, G. A., LeGrande, A. N., and Hoffmann, G.: Water isotope expressions of intrinsic and forced variability in a coupled ocean-atmosphere model, J. Geophys. Res., 112, D10103, doi:10.1029/2006JD007781, http://www.agu.org/pubs/crossref/ 2007/2006JD007781.shtml, 2007.

Schneider, D. P. and Noone, D. C.: Spatial covariance of water isotope records in a global network of ice cores spanning twentieth-century climate change, J. Geophys. Res., 112,
D18105, doi:10.1029/2007JD008652, http://www.agu.org/pubs/ crossref/2007/2007JD008652.shtml, 2007.

Schotterer, U., Oldfield, F., and Froehlich, K.: GNIP - Global Network for Isotopes in Precipitation, Laederach AG, Bern, Switzerland, 1996a.

Sime, L. C., Tindall, J. C., Wolff, E. W., Connolley, W. M., and Valdes, P. J.: Antarctic isotopic thermometer during a $\mathrm{CO}_{2}$ forced warming event, J. Geophys. Res., 113, D24119, doi:10.1029/2008JD010395, http://www.agu.org/pubs/crossref/ 2008/2008JD010395.shtml, 2008.

Solomon, S., Qin, D., Manning, M., Alley, R., Berntsen, T., Bindoff, N., Chen, Z., Chidthaisong, A., Gregory, J., Hegerl, G., Heimann, M., Hewitson, B., Hoskins, B., Joos, F., Jouzel, J., Kattsov, V., Lohmann, U., Matsuno, T., Molina, M., Nicholls, N., Overpeck, J., Raga, G., Ramaswamy, V., Ren, J., Rusticucci, M., Somerville, R., Stocker, T., Whetton, P., Wood, R., and Wratt, D.: Climate Change 2007: The Physical Science Basis. Contribution of Working Group I to the Fourth Assessment Report of the Intergovernmental Panel on Climate Change, Cambridge University Press, online available at: http://ipcc-wg1.ucar.edu/ wg1/wg1-report.html, 2007.

Sturm, C. K., Hoffmann, G., Langmann, B., and Stichler, W.: Simulation of $\delta^{18} O$ in precipitation by the regional circula-

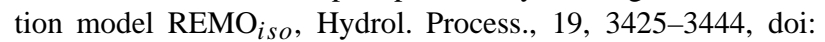
10.1002/hyp.5979, 2005.

Thompson, L. G.: Ice core evidence for climate change in the Tropics: implications for our future, Quaternary Sci. Rev., 19, 19-35, doi:10.1016/S0277-3791(99)00052-9, http: //www.sciencedirect.com/science/article/B6VBC-40378TB-4/2/ 1f08f9aa12b72d0097d8d4cfd526f30a, 2000.

Tindall, J. C., Valdes, P. J., and Sime, L. C.: Stable water isotopes in HadCM3: Isotopic signature of El Niño Southern Oscillation and the tropical amount effect, J. Geophys. Res., 114, D04111, doi:10.1029/2008JD010825, http://www.agu.org/pubs/ crossref/2009/2008JD010825.shtml, 2009.

Trenberth, K. E., Jones, P. D., Ambejene, P., Bojariu, R., Easterling, D., Klein Tank, A., Parker, D. E., Rahimzadeh, F., Renwick, J. A., Rusticucci, M., Soden, B., and Zhai, P.: Observations: surface and atmospheric climate change, in: Climate Change 2007: the physical science basis, Cambridge University Press, online available at: http://ipcc-wg1.ucar.edu/wg1/Report/ AR4WG1_Print_Ch03.pdf, 2007.

Vimeux, F., Gallaire, R., Bony, S., Hoffmann, G., and Chiang, J. C.: What are the controls on $\delta D$ in precipitation in the Zongo Valley (Bolivia)? Implications for the Illimani ice core interpretation, Earth Planet. Sci. Lett., 240, 205-220, doi:10.1016/j.epsl.2005. 09.031, 2005.

Werner, M., Mikolajewicz, U., Heimann, M., and Hoffmann, G.: Borehole versus isotope temperatures on Greenland : seasonality does matter, Geophys. Res. Lett., 27, 723-726, 2000.

Yoshimura, K., Kanamitsu, M., Noone, D., and Oki, T.: Historical isotope simulation using Reanalysis atmospheric data, J. Geophys. Res., 113, D19108, doi:10.1029/2008JD010074, http: //www.agu.org/pubs/crossref/2008/2008JD010074.shtml, 2008. 